\title{
KOMBINASI BUAH LADA HITAM (PIPER NIGRUM L. ) DAN JAHE MERAH (ZINGIBER OFFICINALE) SEBAGAI CREAM UNTUK MENGOBATI PENYAKIT VITILIGO
}

\author{
Fitriana Ikhtiarinawati Fajrin ${ }^{1}$, Mimatun Nasihah² \\ (Universitas Islam Lamongan)
}

\begin{abstract}
Black pepper and red ginger the results of natural wealth with many benefits. The aim of this study was to determine the effectiveness of black pepper cream with red ginger combination in treating vitiligo. Using the experimental method. Data collection includes $\mathrm{pH}$ test, effectiveness test of black pepper cream combination of red ginger and pharmaceutical test. Data analysis used T-Paired Test to determine differences area of exposure before and after treatment. The $\mathrm{pH}$ test for the cream product resulted in a $\mathrm{pH}$ of 6 . The pharmaceutical test explained that the cream was homogeneous, had a semi-solid form, had a distinctive odor, was brownish yellow in color and had a spreadability of $5.7 \mathrm{~cm}$. The results showed that the combination of red ginger black pepper seed cream was effective in treating vitiligo with a $T$ count value of 4.583> T table 2.131. In conclusion, there is a significant difference in the extent of vitiligo exposure to the skin before and after being given black pepper cream with red ginger combination. It is hoped that there will be further research to find out the content of black pepper and ginger which plays a role in treating vitiligo and it is hoped that the results of this study will be used as a mass-produced product and its benefits can be felt by the community, especially those with vitiligo.
\end{abstract}

Keywords: Black Pepper; Red Ginger; Cream; Vitiligo

\begin{abstract}
Abstrak
Lada hitam dan Jahe merah merupakan hasil kekayaan alam nabati yang banyak manfaat. Tujuan penelitian ini untuk mengetahui efektivitas cream lada hitam kombinasi jahe merah dalam mengobati penyakit vitiligo. Menggunakan metode eksperimen. Pengumpulan data meliputi uji $\mathrm{pH}$, uji efektivitas cream lada hitam kombinasi jahe merah dan uji farmasetika. Analisis data menggunakan Uji T-Paired untuk mengetahui perbedaan paparan vitiligo sebelum dan sesudah perlakuan. Uji pH produk cream menghasilkan $\mathrm{pH}$ 6. Uji Farmasetika menjelaskan bahwa cream homogen, bentuk semi solida, berbau khas, warna kuning kecoklatan dan mempunyai daya sebar $5,7 \mathrm{~cm}$. Hasil penelitian menunjukan bawah cream biji lada hitam kombinasi jahe merah efektif dalam mengobati penyakit vitiligo dengan nilai $T$ hitung sebesar $4.583>T$ tabel 2.131. Simpulannya terdapat perbedaan yang signifikan luas paparan vitiligo pada kulit sebelum dan sesudah diberi cream lada hitam kombinasi jahe merah. Diharapkan ada penelitian lanjutan untuk mengetahui kandungan lada hitam dan jahe yang berperan dalam mengobati penyakit vitiligo dan diharapkan hasil penelitian ini dijadikan sebagai produk yang diproduksi massal dan bisa dirasakan manfaatnya oleh masyarakat terutama penderita vitiligo.
\end{abstract}

Kata kunci: Lada Hitam; Jahe Merah; Cream; Vitiligo 


\section{PENDAHULUAN}

Menurut British Journal of Dermatology, Penelitian yang dilakukan oleh peneliti King's Collage London berhasil mengungkap manfaat piperin yang terkandung didalam lada hitam mampu merangsang pigmentasi pada kulit. Selain itu hasil penelitian yang dilakukan oleh menjelaskan bahwa creamBuah Lada Hitam (Piper nigrum) sebagai obat vitiligo memberikan hasil yang cukup signifikan bahwa terdapat perubahan yang terhadap luas paparan penyakit vitiligo pada kulit, akan tetapi proses perubahannya cukup lambat ${ }^{1}$.Seperti kita ketahui bahwa vitiligo merupakan penyakit yang menyebabkan terbentuknya bercakbercak putih pada kulit. Penyakit ini dapat terjadi pada segala usia, tapi umumnya sebelum pengidap berusia 20 tahun. Perkembangan vitiligo sulit diprediksi karena umumnya berbeda-beda pada tiap penderita. Ada yang mengalami penyebaran bercak dengan cepat dan ada yang lambat. Sebagian besar penderitanya kehilangan pigmen kulit secara perlahan-lahan pada hampir seluruh permukaan kulit ${ }^{1}$.

Menurut penelitian yang dilakukan oleh Sadikim (2018) menjelaskan bawah terdapat pengurangan luas paparan vitiligo pada kulit dalam masa pengobatan satu bulan rata-rata berkisar 0,2 hingga $0.4 \mathrm{~cm}$, butuh waktu yang cukup lama untuk mengobati penyakit ini. Dalam upaya mempercepat penyempitan luas paparan vitiligo dikulit, maka perlu dilakukan penelitian lanjutan dengan memberikan kombinasi cream dengan bahan dasar lada hitam dengan jahe merah. Selain kandungan kolagen yang tinggi, jahe merah juga mengandung asam chlorogenic dan farnesol yang mampu meregenerasi sel. Hal ini berdasar pada penelitian yang dilakukan oleh Nasihah menjelaskan bahwa Jahe merah lebih banyak dimanfaatkan sebagai bahan baku obat karena memiliki kandungan oleoresin (3\%) dan minyak atsiri $(2,58-2,72 \%)$ yang lebih tinggi dibandingkan kedua jahe lainnya ${ }^{2}$. Fungsi minyak atsiri sebagai anti bakteri. Oleoresin yang terdiri dari senyawa asam alpha-linolenic berfungsi sebagai anti pendarahan, quercetin sebagai anti oksidan, 6-gingerdion, 10dehidrogingerdion, 8-paradol, 6- dehidroparadol, dan capsain sebagai anti inflamasi , 6gingerol, 8-gingerol, dan 10-gingerol sebagai anti bakteri10 serta anti inflamasi, asam chlorogenic dan farnesol sebagai perangsang regenerasi sel, 6- shogaol, 8-shogaol dan 10shogaol sebagai anti oksidan, anti bakteri, anti inflamasi , angiogenesis, serta proliferasi fibroblast ${ }^{2}$.

Selain itu Jahe dapat membantu meningkatkan imunitas dan juga meningkatkan sirkulasi darah, jahe akan merangsang produksi melanosit dan perlahan akan mendorong regenerasi kulit yang tidak rata. Didalam jahe terdapat kandungan zat collagen yang memiliki manfaat yang sangat baik dalam menghilangkan bercak putih pada permukaan kulit.Jenis jahe yang paling bagus dalam mengatasi penyakit vitiligo ialah jahe merah karena kandungan yang terdapat dalam jahe merah sangatlah lengkap, jahe merah dipercaya dapat memulihkan selsel jahat yang berada pada kulit atau memulihkan kulit yang rusak secara alami, jahe merah 
sangat efektif dalam menghilangkan penyakit vitiligo karena mengandung kolagen, penggunaan jahe dalam mengatasi penyakit vitiligo sangat aman tanpa menimbulkan efek samping ${ }^{3}$.

Menurut penelitian yang dilakukan oleh Rahmayanti, 2016. Menjelaskan bahwa Prevalensi vitiligo pada populasi diperkirakan berkisar dari $0,1 \%-2 \%$ dan menunjukkan adanya variasi yang luas diantara kelompok etnis yang berbeda. Prevalensi vitiligo pada populasi Kaukasia di Amerika Serikat dan Eropa Utara diperkirakan sebesar 0,38\%, sedangkan pada populasi di Cina diperkirakan sebesar 0,19\%. Berdasarkan data rekam medis pasien vitiligo di Divisi Kosmetik Medik Unit Rawat Jalan IImu Kesehatan Kulit dan Kelamin RSUD Dr. Soetomo Surabaya pada tahun 2009-2011, dari total 21.405 pasien yang periksa ke Unit Rawat Jalan IImu Kesehatan Kulit dan Kelamin, didapatkan 330 pasien vitiligo ${ }^{4}$.

Hal inilah yang melatarbelakangi kami untuk membuat ide pemanfaatan lada hitam yang dikombinasikan dengan jahe merah untuk mengobati penyakit vitiligo. Hal ini juga ditunjang oleh semakin banyaknya jumlah penderita penyakit vitiligo tanpa penanganan yang cukup berarti. Diharapkan penelitian ini dapat diaplikasikan sebagai pengembangan produk Buah Lada Hitam kombinasi jahe merah. Karena berbahan organik sehingga aman, mudah dan murah didapatkan oleh para konsumen. Spesifikasi khusus dari penelitian yang akan kami lakukan adalah pembuatan produk creambuah lada hitam kombinasi jahe merah untuk mengobati penyakit vitiligo.

\section{METODE PENELITIAN}

Metode penelitian yang dilakukan pada penelitian ini adalah metode eksperimen uji coba rekayasa produk. Metode eksperimental merupakan metode penelitian yang memungkinkan peneliti memanipulasi variabel dan meneliti akibat-akibatnya. Desain yang digunakan adalah pretest- posttest Control Design. Dalam desain ini terdapat dua kelompok yang dipilih secara random. kemudian diberi pretest untuk mengetahui keadaan awal adakah perbedaan antara kelompok eksperimen dan kelompok kontrol. Pada metode ini variabel-variabel dikontrol sedemikian rupa, sehingga variabel luar yang mungkin mempengaruhi dapat dihilangkan. Penelitian ini menggunakan bahan dasar lada hitam kombinasi jahe merah dan emulgade sebagaibasis cream dengan perbandingan yang berbeda sehingga menghasilkan cream untuk mengobati penyakit vitiligo. Cream lada hitam kombinasi jahe merah merupakan variable bebas, penyempitan luas paparan vitiligo pada kulit merupakan variable terikatnya. Penelitian ini dilaksanakan selama satu bulan, setelah itu dilihat perbedaan luas paparan vitiligo.

Lokasi penelitian produk cream Buah Lada Hitam kombinasi jahe merah adalah Laboratorium Universitas Islam Lamongan

\section{a. Pembuatan serbuk Buah Lada Hitam}


Desain Penelitian

\section{CREAM BIJI LADA HITAM (Piper nigrum L).KOMBINASI JAHE MERAH (Zingiber Officinale) SEBAGAI OBAT VITILIGO}

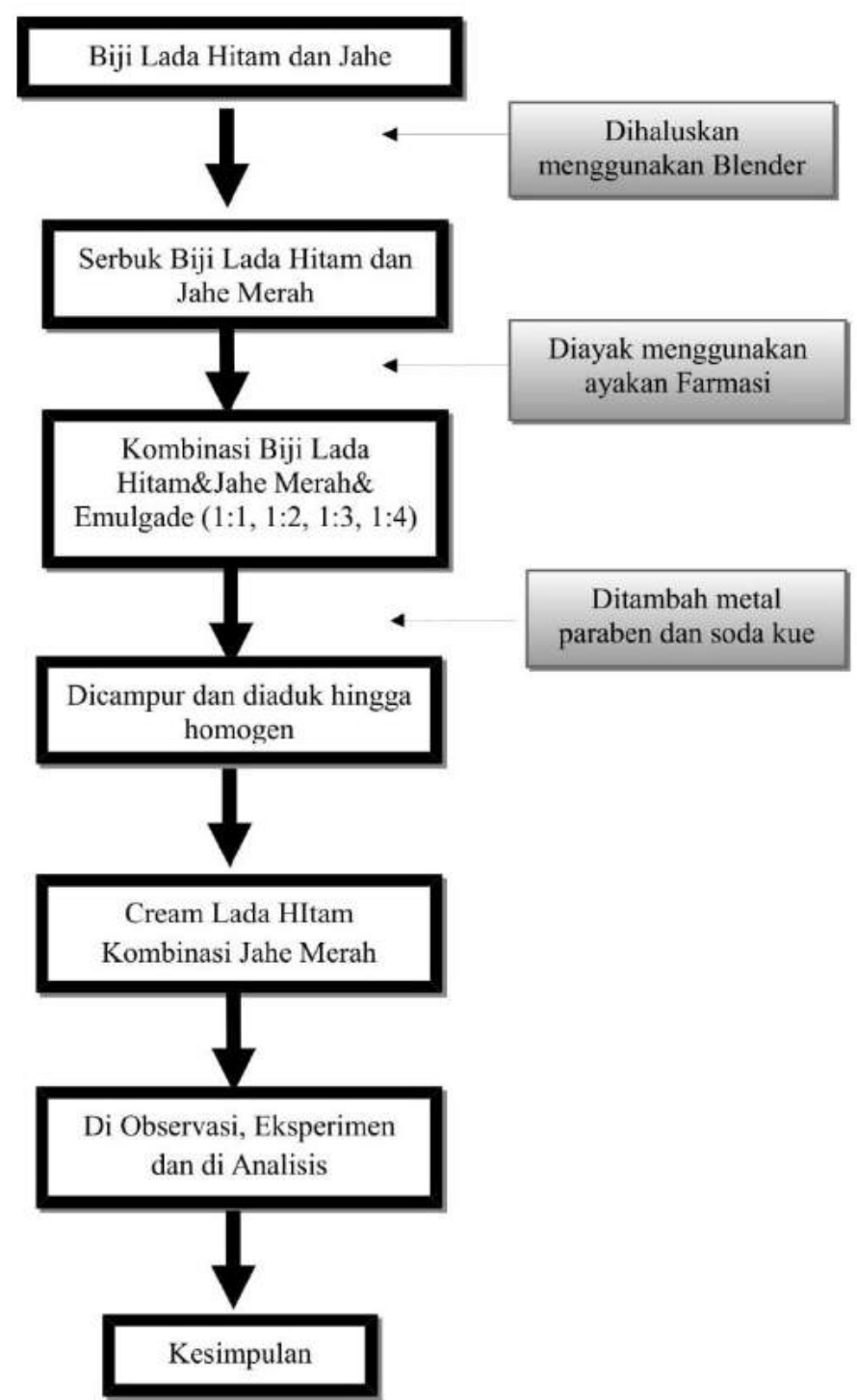

\section{Gambar 1. Desain Pembuatan Cream Lada Hitam kombinasi Jahe Merah}

Alat yang digunakan yaitu Timbangan milligram, Blender, sudip, Pipet tetes, $\mathrm{pH}$ meter, gelas ukur, ayakan, kertas filter, baskom, pengaduk, plastik, cawan petri. Sedangkan bahan yang digunakan yaitu Biji Lada Hitam, Jahe merah, emulgade, methyl paraben, soda kue, akuades.

\section{Pelaksanaan Penelitian}

a) Buah Lada Hitam di sortir kemudian diblender menjadi serbuk lada hitam.

b) Jahe merah diiris menjadi bagian kecil-kecil, dikeringkan baru diblender. Sehingga menghasilkan serbuk jahe merah 
c) Serbuk lada hitam dan jahe merah kemudian dicampur dengan beberapa bahan yang lain, antara lain emulgade, methyl parabensehingga terbentuk cream.

d) Kombinasi Bahan biji lada hitam+jahe merah+emulgade masing masing 1:1:2, 1:1:2, $1: 3: 8,2: 1: 10$ dan $1: 2: 12$

e) Semua bahan dicampur dan di lakukan pengujian kemudian dianalisis dan ditarik kesimpulan

\section{Pemilihan Partisipan}

Teknik sampling yang digunakan oleh peneliti adalah purposive sample yakni teknik penentuan sampel dengan pertimbangan tertentu. Pada penelitian ini pemilihan partisipan menggunakan teknik purposive yaitu pengambilan partisipan sebagai sumber data dengan pertimbangan tertentu dan berdasarkan kriteria yang telah ditentukan yakni partisipan yang berpenyakit vitiligo. Kriteria partisipan yang akan diambil pada penelitian ini berdasarkan pada:

a) Mengidap penyakit vitigo

b) Partisipan dapat berkomunikasi dengan baik

c) Bersedia menjadi partisipan

\section{Teknik Pengumpulan dan Analisis Data}

a) Uji pH.Uji $\mathrm{pH}$ dilakukan dengan melarutkan produk cream diencerkan menggunakan aquadest kemudian diukur dengan $\mathrm{pH}$ meter. Menurut Wasiaatmaja (2006) pH yang normal untuk kulit adalah 4,5-6.

b) Pengamatan visual paparan kulit atas penyakit vitiligo. Cream diaplikasikan pada kulit 3 kali dalam seminggu sampai jangka waktu 1 bulan dan dilakukan pada pagi hari sekitar jam 8 hingga jam 10 pagi. Setelah itu kemudian dibandingkan lebar paparan vitiligo antara sebelum diberi cream dengan sesudah. Untuk akurasi data, proses perbandingan bisa dilakukan dengan mengambil foto/gambar keadaan paparan penyakit vitiligo pada kulit sebelum diberi cream. Hasil pengamatan di dokumentasi dan ditarik kesimpulan.

c) Uji Farmasetika. Dari pengamatan organoleptik di ambil satu sampel yang dianggap terbaik dari ketiga unsur tersebut kemudian diuji kandungan mikroorganisme dan uji farmasetika pada produk cream Buah Lada Hitam kombinasi jahe merah. Pengujian dilakukan di Laboratorium Farmasi Akademi Farmasi Surabaya.

d) Analisis Data. Analisis data dilakukan dengan menggunakan uji Anova dan Uji T-Paired untuk mengetahui perbedaan signifikan antara sebelum penggunaan cream dan sesudah penggunaan cream. 


\section{HASIL PENELITIAN}

\section{Formulasi Cream Lada Hitam Kombinasi Jahe Merah}

Lada hitam dan bahan basis cream diformulasikan dengan berbagai macam variasi persentase lada hitam sehingga menghasilkan formulasi yang disajikan dalam tabel berikut:

Tabel 1. Formula Cream dengan variasi dasar salep

\begin{tabular}{ccccc}
\hline Perlakuan & Lada Hitam & Jahe Merah & Emulgade & Metyl Paraben \\
\hline Perlakuan 1 $(1: 1: 2)$ & $2.5 \mathrm{gram}$ & $2.5 \mathrm{gram}$ & $5 \mathrm{gram}$ & $0.2 \mathrm{gram}$ \\
Perlakuan 3 $(1: 1: 2)$ & $5 \mathrm{gram}$ & $5 \mathrm{gram}$ & $10 \mathrm{gram}$ & $0.2 \mathrm{gram}$ \\
Perlakuan 5 $(1: 3: 8)$ & $2.5 \mathrm{gram}$ & $7.5 \mathrm{gram}$ & $20 \mathrm{gram}$ & $0.2 \mathrm{gram}$ \\
Perlakuan 7 $(2: 1: 10)$ & $5 \mathrm{gram}$ & $2.5 \mathrm{gram}$ & $25 \mathrm{gram}$ & $0.2 \mathrm{gram}$ \\
Perlakuan 9 $(1: 2: 12)$ & $2.5 \mathrm{gram}$ & $5 \mathrm{gram}$ & $30 \mathrm{gram}$ & $0.2 \mathrm{gram}$ \\
\hline
\end{tabular}

Cream dibuat dengan mencampurkan ekstrak lada hitam dan ekstrak jahe merah dengan basis cream berupa emulgade. Variasi perbandingan antara ekstrak lada hitam. Ekstrak jahe merah dengan basis cream dibuat berbeda. Tujuannya untuk mengetahui formulasi mana yang bisa menghasilkan cream yang paling baik dan bisa diaplikasikan dengan optimal sekaligus menghasilkan efek yang optimal juga. Perbandingan formulasi antara ekstrak lada hitam, ekstrak jahe merah dengan masing-masing basis cream masingmasing yakni yakni : (1:1:2), (1:1:2), (1:3:8), (2:1:10), (1:2:12). Perbedaan perbandingan formulasi sebanyak 5 macam, hal ini kami lakukan untuk menghasilkan cream yang berbeda dan yang dapat menentukan mana cream yang paling baik.

\section{Uji Derajat Keasaman (pH)}

Uji pH yang dilakukan menghasilkan tabel seperti dibawah ini:

Tabel 2. Uji pH pada Cream Biji Lada Hitam

\begin{tabular}{ccc}
\hline NO & PERLAKUAN & pH \\
\hline $\mathbf{1}$ & Lada Hitam:Jahe Merah:Emulgade $(2.5: 5: 2,5)$ & 6 \\
$\mathbf{2}$ & Lada Hitam:Jahe Merah:Emulgade $(5: 5: 10)$ & 6 \\
$\mathbf{3}$ & Lada Hitam:Jahe Merah:Emulgade $(2.5: 7: 20)$ & 6 \\
$\mathbf{4}$ & Lada Hitam:Jahe Merah:Emulgade $(5: 2.5: 25)$ & 6 \\
$\mathbf{5}$ & Lada Hitam:Jahe Merah:Emulgade $(2.5: 5: 30)$ & 6 \\
\hline
\end{tabular}

Dari data yang didapat seperti yang tertera dalam tabel 2, diketahui bahwa dari ke 5 perlakuan mempunyai nilai pH yang sama yakni 6 atau normal.

\section{Uji Efektivitas Cream Lada Hitam terhadap Penyakit Vitiligo}

Uji efektivitas cream lada hitam kombinasi jahe merah dilakukan dengan mengoleskan cream pada kulit manusia yang terpapar penyakit vitiligo. Pengujian ini dilakukan pada kulit responden yang terpapar penyakit vitiligo. Cream hasil percobaan diaplikasikan ke kulit pada bagian yang terpapar vitiligo dalam waktu tiga hari sekali selama satu bulan. Pemakaian 
cream lada hitam kombinasi jahe merah dilakukan pada pagi hari antara jam 8 hingga jam 10 pagi. Setelah memakai cream lada hitam kombinasi jahe merah kulit dipaparkan dibawah sinar matahari selama kurang lebih 3-5 menit kemudian diamati reaksi yang terjadi. Reaksinya secara langsung adalah adanya efek memerah pada kulit. Selain itu setelah 1 bulan perlakuan dilakukan pengamatan terhadap perubahan luas paparan penyakit vitiligo.



\section{Gambar 2. Grafik Perbandingan Luas Paparan Vitiligo sebelum dan sesudah perlakuan}

Dari data yang terlihat pada Grafik 2. dapat diketahui bahwa terdapat perbedaan luas paparan vitiligo sebelum dan sesudah pemberian cream lada hitam. Pemberian cream lada hitam diberikan dua kali dalam satu minggu. Aplikasi cream dilakukan pada pagi hari sekitar jam 08.00 pagi hingga 10.00 pagi. Setelah cream lada hitam dioleskan kemudian dipaparkan dibawah sinar matahari selama kurang lebih 3-5 menit. Paparan sinar matahari membantu mempercepat proses kerja cream lada hitam dalam pembentukan melanin kulit.

Dari hasil pengamatan tersebut dapat diketahui bahwa terdapat perbedaan luas paparan vitiligo antara sebelum dan sesudah pemakaian cream lada hitam kombinasi jahe merah. Seperti yang terlihat pada gambar 6 menunjukan luas paparan pada responden satu adalah $1 \mathrm{~cm}$, setelah 1 bulan pemakaian mengalami menyempitan luas paparan menjadi 0,9 $\mathrm{cm}$. responden selanjutnya luas paparan sebelum perlakuan $3 \mathrm{~cm}$ setelah diberi cream lada hitam kombinasi jahe merah mengalami penyempitan luas paparan vitiligo menjadi $2,9 \mathrm{~cm}$. pada area ke 3 , luas paparan sebelum perlakuan sebesar $3 \mathrm{~cm}$ dan setelah perlakuan sebesar 2,9 cm. Pada area ke 4, luas paparan vitiligo $1 \mathrm{~cm}$ setelah satu bulan menjadi 0,9 cm hingga pada area ke 15, luas paparan vitiligo $0,6 \mathrm{~cm}$ menjadi $0.4 \mathrm{~cm}$.

Hasil dari uji efektivitas cream lada hitam kombinasi jahe merah terhadap penyakit vitiligo kemudian di analisis dengan menggunakan uji $T$ Paired dengan memanfaatkan software SPSS yaitu software yang dikhususkan untuk membuat analisis statistik. Pengujian dengan uji ini dimaksudkan untuk mengetahui apakah terdapat perbedaan paparan vitiligo antara sebelum diberi cream lada hitam kombinasi jahe merah dengan sesudah diberi cream lada hitam kombinasi jahe merah. 
Tabel 3. Hasil Uji T Paired terhadap Perubahan Paparan Vitiligo antara sebelum dan sesudah diberi cream lada hitam

\begin{tabular}{|c|c|c|c|c|c|c|c|c|c|}
\hline \multicolumn{10}{|c|}{ Paired Samples Test } \\
\hline & & \multicolumn{5}{|c|}{ Paired Differences } & \multirow[t]{3}{*}{$\mathrm{t}$} & \multirow[t]{3}{*}{ df } & \multirow{3}{*}{$\begin{array}{l}\text { Sig. (2- } \\
\text { tailed) }\end{array}$} \\
\hline & & \multirow[t]{2}{*}{ Mean } & \multirow[t]{2}{*}{$\begin{array}{c}\text { Std. } \\
\text { Deviation }\end{array}$} & \multirow[t]{2}{*}{$\begin{array}{l}\text { Std. } \\
\text { Error } \\
\text { Mean }\end{array}$} & \multicolumn{2}{|c|}{$\begin{array}{l}95 \% \text { Confidence } \\
\text { Interval of the } \\
\text { Difference }\end{array}$} & & & \\
\hline & & & & & Lower & Upper & & & \\
\hline Pair 1 & $\begin{array}{l}\text { Sebel } \\
\text { um - } \\
\text { Sesud } \\
\text { ah }\end{array}$ & $\begin{array}{r}.7000 \\
0\end{array}$ & .48305 & .15275 & .35445 & $\begin{array}{r}1.0455 \\
5\end{array}$ & 4.583 & 9 & .001 \\
\hline
\end{tabular}

Berdasarkan Tabel 3. dapat dijelaskan bahwa hasil Uji T Test Paired tentang efektivitas cream terhadap luas paparan vitiligo pada kulit diproleh nilai $T$ hitung sebesar 4.583 sedangkan nilai $\mathrm{T}$ tabel adalah sebesar 2.131 sehingga nilai $\mathrm{T}$ hitung $>\mathrm{T}$ tabel . Oleh karena itu maka dapat diartikan bahwa terdapat perbedaan yang signifikan luas paparan vitiligo pada kulit sebelum dan sesudah diberi cream lada hitam kombinasi jahe merah.

\section{Uji Farmakosita Cream Lada Hitam}

Uji Farmasetika meliputi Uji Homogenitas, Uji Organoleptik, pH dan Uji Daya Sebar seperti pada tabel dibawah ini:

Tabel 4. Hasil Uji Farmasetika Cream Biji Lada Hitam kombinasi Jahe Merah

\begin{tabular}{lcc}
\hline No & Jenis Uji & Hasil Uji \\
\hline $\mathbf{1}$ & Homogenitas & Homogen, Tidak Menggumpal \\
$\mathbf{2}$ & Organoleptik & Bentuk : Setengah Padat \\
& & Bau : Berbau Khas \\
& & Warna : Coklat Kekuningan \\
$\mathbf{3}$ & Ph & 6 \\
$\mathbf{4}$ & Daya Sebar & $5,7 \mathrm{~cm}$ \\
\hline
\end{tabular}

Dari Tabel 4. diatas dapat diketahui bahwa hasil uji Homogenitas cream biji lada hitam kombinasi jahe merah adalah homogen, semua bahan tercampur dengan merata dan menyatu, produk cream tidak menggumpal. Hasil uji organoleptik menunjukan bahwa bentuk cream lada hitam kombinasi jahe merah berbentuk setengah padat dengan bau khas lada hitam bercampur dengan bau khas jahe merah, warna cream adalah coklat kekuningan. Hasil uji $\mathrm{pH}$ didapat $\mathrm{pH}$ cream lada hitam kombinasi jahe merah adalah 6. Selanjutnya dilakukan pengujian daya sebar dilakukan untuk menjamin pemerataan cream lada hitam kombinasi jahe merah saat diaplikasikan pada kulit. Hasil uji daya sebar cream biji lada hitam kombinasi jahe merah dengan menggunakan beban sebesar 1000 gram daya sebarnya $5.2 \mathrm{~cm}$. Pengujian daya sebar dilakukan dengan cara sejumlah cream diletakkan diatas kaca yang berskala, kemudian bagian atasnya diberi kaca yang sama dan ditingkatkan bebannya, kemudian diberi rentang waktu 1-2 menit, kemudian diameter 
penyebaran diukur pada setiap penambahan beban dan diukur setelah cream berhenti menyebar ${ }^{5}$.

\section{PEMBAHASAN}

Bagian ini menyajikan pembahasan hasil penelitian. Bagian pembahasan memaparkan hasil pengolahan data, menginterpretasikan penemuan secara logis, mengaitkan dengan sumber rujukan yang relevan. [Arial, 11, normal], spasi 1,5. Format gambar png/jpg]. Basis cream yang digunakan adalah emulgade. Hasil penelitian yang dilakukan oleh Susila (2019) dijelaskan bahwa cream dibuat dengan mencampurkan lada hitam dengan empat macam basis cream yang berbeda. Variasi perbandingan antara lada hitam dengan dasar cream dibuat sama. Tujuannya untuk mengetahui basis cream mana yang paling baik digunakan sehingga menghasilkan cream yang baik dan bisa digunakan dengan optimal sekaligus menghasilkan efek yang optimal juga. Adapun basis cream yang digunakan antara lain vaselin, adeps lanae, emulgade dan cera flava\&aleum sesame. Basis cream yang digunakan mempunyai karakter yang berbeda-beda. Vaselin mempunyai karakter berminyak, yang sulit bercampur dengan air, begitu juga dengan adebs lanae, yang berasal dari minyak domba. Basis cream jenis ini juga sulit bercampur dengan air, sementara emulgade mempunyai sifat konsisten, membentuk tekstur yang halus, bersifat dapat bercampur dengan air dan juga bisa melembabkan kulit dan cera flava dan aleum sesame, karena mengandung minyak maka juga sulit bercampur dengan air ${ }^{1}$.

Menurut Hasil penelitian yang dilakukan oleh Sari (2017) menjelaskan bahwa pemilihan dasar salep merupakan salah satu hal yang harus diperhatikan dalam pembuatan salep. Dasar salep yang akan digunakan yaitu dasar salep hidrokarbon dan dasar salep serap. Dasar salep hidrokarbon dikenal sebagai dasar salep berlemak yang dimaksudkan untuk memperpanjang kontak bahan obat dengan kulit dan bertindak sebagai pembalut penutup. Dasar salep hidrokarbon digunakan terutama sebagai emolien, tidak mengering, dan tidak tampak berubah dalam waktu yang lama. Dasar salep serap juga bermanfaat sebagai emolien. Pemilihan kedua dasar salep tersebut karena merupakan dasar salep yang tidak mengandung air karena bahan aktif yang akan dicampurkan mengandung kurkumin dan minyak atsiri yang kurang larut dalam air ${ }^{6}$.

Diketahui bahwa emulgade mempunyai sifat konsisten, membentuk tekstur yang halus, bersifat dapat bercampur dengan air dan juga bisa melembabkan kulit sehingga mudah diaplikasikan pada kulit. Oleh karenanya dalam penelitian ini kita menggunakan basis cream emulgade dengan formulasi perbandingan yang berbeda, penelitian ini melanjutkan penelitian sebelumnya yakni selain menggunakan basis cream emulgade juga menambah formulasi yakni dengan mengkombinasikan lada hitam dan jahe merah. Seperti penelitian yang dilakukan oleh Putu (2016) menjelaskan bahwa Piperin merupakan senyawa alkaloid 
utama dalam buah lada. Piperin memiliki khasiat sebagai antiinflamasi, antimalaria, menurunkan berat badan, menurunkan demam, menetralkan racun bisa ular, antiepilepsi, membantu meningkatkan penyerapan vitamin tertentu. Hasil sintesis dari piperin akan membantu menstimulasi pigmentasi kulit pada penderita vitiligo ${ }^{7}$.

Penggunaan Jahe merah dalam pembuatan cream ini didasarkan atas penelitian yang dilakukan oleh Sadikim (2018) menyatakan bahwa jahe merah lebih banyak dimanfaatkan sebagai bahan baku obat karena memiliki kandungan oleoresin (3\%) dan minyak atsiri $(2,58-2,72 \%)$ yang lebih tinggi dibandingkan kedua jahe lainnya. Fungsi minyak atsiri sebagai anti bakteri. Oleoresin yang terdiri dari senyawa asam alpha-linolenic berfungsi sebagai anti pendarahan, quercetin sebagai anti oksidan, 6-gingerdion, 10dehidrogingerdion, 8-paradol, 6-dehidroparadol, dan capsain sebagai anti inflamasi, 6gingerol, 8-gingerol, dan 10-gingerol sebagai anti bakteri serta anti inflamasi, asam chlorogenic dan farnesol sebagai perangsang regenerasi sel , 6- shogaol, 8-shogaol dan 10shogaol sebagai anti oksidan, anti bakteri, anti inflamasi, angiogenesis, serta proliferasi fibroblast ${ }^{2}$.

Metil paraben digunakan untuk mengontrol pertumbuhan jamur pada obat-obatan, kosmetik, dan beberapa produk makanan. Penelitian menunjukkan substansi ini tidak beracun. Metil Paraben yang digunakan sebagai zat pengawet yang berfungsi mencegah atau menghambat pertumbuhan mikroba sehingga dapat melindungi cream dari kerusakan. Penggunaan methyl paraben hanya sebesar 0.2 gram saja karena batas maksimum penggunaannya berdasarkan keputusan kepala BPOM RI No HK.00.05.4.1745 adalah sebesar $0,4 \%$. Perlu diketahui bahwa karakter cream yang baik adalah dapat tercampur baik dengan bahan obat, stabil dalam penyimpanannya, mudah dicuci dengan air, mudah melepaskan bahan obat, mudah diformulasikan, reaksinya bersifat netral dan secara fisik bersifat halus dan kental ${ }^{8}$.

Uji pH dilakukan untuk keamanan produk tersebut ketika digunakan. Derajat keasaman $(\mathrm{pH})$ merupakan pengukuran aktivitas hidrogen dalam lingkungan air. Berdasarkan SNI 164399-1996 dalam Nasihah (2019) bahwa nilai pH produk obat kulit kulit disyaratkan berkisar antara 4,5-8,0 ${ }^{9}$. Nilai pH tidak boleh terlalu asam karena mengakibatkan iritasi pada kulit, sedangkan jika $\mathrm{pH}$ terlalu basa akan mengakibatkan bersisik pada kulit ${ }^{10}$. Seperti hasil penelitian yang dilakukan sebelumnya menjelaskan bahwa hasil uji pH pada produk cream lada hitam adalah sebesar 7 .

Dari data hasil uji $\mathrm{pH}$ pada semua produk cream lada hitam kombinasi jahe merah dengan variasi formulasi yang berbeda menghasilkan ukuran $\mathrm{pH}$ yang sama semua yakni pH 6. $\mathrm{pH} 6$ menunjukan bahwa Nilai $\mathrm{pH} 6$ dikatakan netral karena pada air murni ion $\mathrm{H}_{+}$ terlarut (sebagai tanda kebasaan) berada pada jumlah yang sama yakni 10-7 kesetimbangan. Data tersebut menunjukkan bahwa semua produk cream lada hitam 
kombinasi jahe merah semuanya mempunyai $\mathrm{pH}$ normal. Seperti kita ketahui bersama bahwa $\mathrm{pH}$ normal untuk kulit berkisar antara 4.5 sampai 8.0 sehingga cream yang diaplikasikan pada kulit tidak akan memberikan efek yang negatif karena terlalu asam atau terlalu basa.

Perubahan luas paparan vitiligo ini sejalan dengan hasil penelitian yang dilakukan oleh Nasihah (2019) yang menyatakan bahwa terdapat perbedaan luas paparan vitiligo antara sebelum dan sesudah pemakaian cream lada hitam. Seperti yang bisa kita lihat pada area kepala luas paparan vitiligo sebelum diberi cream adalah $4 \mathrm{~cm}$ kemudian setelah satu bulan diberi cream luas paparanya menyempit menjadi $3 \mathrm{~cm}$. begitu juga pada daerah siku, dapat dilihat luas paparan vitiligo awal seluas $1.5 \mathrm{~cm}$ kemudian satu bulan kemudian menjadi 1.1 $\mathrm{cm}$. paparan vitiligo pada bahu dan pergelangan tangan, sebelum diberi cream lada hitam luas paparanya sebesar $1.2 \mathrm{~cm}$, setelah satu bulan diberi cream lada hitam luasnya menjadi $0.3 \mathrm{~cm}$. begitu juga pada daerah leher, luas paparan vitiligo sebelum diberi aplikasi cream lada hitam seluas $1.2 \mathrm{~cm}$ kemudian setelah satu bulan berubah menjadi $1 \mathrm{~cm}{ }^{11}$. Hal ini juga sejalan dengan penelitian yang dilakukan oleh Nasihah (2019) yang menyatakan bahwa luas paparan pada responden sadalah $1 \mathrm{~cm}$, setelah 1 bulan pemakaian mengalami menyempitan luas paparan menjadi $0,9 \mathrm{~cm}$. responden selanjutnya luas paparan sebelum perlakuan $3 \mathrm{~cm}$ mengalami penyusutan luas paparan menjadi 2,9 cm setelah diberi perlakuan, luas paparan sebelum perlakuan sebesar $3 \mathrm{~cm}$ dan setelah perlakuan sebesar 2,9 cm. Pada area ke 4, luas paparan vitiligo $1 \mathrm{~cm}$ setelah satu bulan menjadi 0,9 cm hingga pada area ke 15, luas paparan vitiligo $0,6 \mathrm{~cm}$ menjadi $0.4 \mathrm{~cm}{ }^{9}$.

Perbedaan kecepatan penyempitan dipengaruhi oleh kondisi kulit dan perbedaan responden. Penelitian kami lakukan pada 3 responden yang terdampak penyakit vitiligo, ke 3 responden menunjukan sedikit perbedaan efek atau reaksi pada luas paparan, responden 1 dan 2 perbedaan luas paparan antara sebelum dan sesudah hampir mirip, sementara pada responden 3 penyempitan luas paparan agak lebih cepat dengan perlakuan selama 1 bulan pemakaian. Hal ini sejalan dengan penelitian Nasihah (2019) yang menyatakan bahwa perbedaan kecepatan penyempitan luas paparan vitiligo ternyata tidak disebabkan karena perbedaan basis cream akan tetapi lebih pada kondisi kulit dan letaknya. Biasanya kalau daerah yang terpapar vitiligo ada diwajah proses reaksi creamnya lebih cepat dari pada dibagian ruas-ruas jari. Hal ini disebabkan karena daerah jari banyak mengandung tulang, sementara pada wajah atau perut proses penyempitan vitiligo lebih cepat karena kulit pada daerah tersebut lebih banyak mengandung lemak ${ }^{12}$.

Seperti kita ketahui bahwa uji homogenitas digunakan untuk mengetahui apakah bahanbahan penyusun cream lada hitam kombinasi jahe merah homogen, hal ini disebabkan karena baik lada hitam maupun jahe merah di ekstraksi sehingga berbentuk ekstrak etanol kental. Seperti penelitian yang dilakukan oleh Nasihah (2018) yang menyatakan bahwa 
produk cream lada hitam kombinasi jahe merah dengan perbandingan (1:3:8) menghasilkan cream dengan warna hijau muda agak kecoklatan, semua bahan tercampur dengan homogen akan tetapi warnanya cukup terang karena basis creamnya jauh lebih banyak daripada bahan-bahan yang lain ${ }^{10}$.

Uji homogenitas sediaan salep dilakukan untuk melihat perpaduan bahan-bahan (basis dan zat aktif) sehingga menjadi bentuk salep yang homogen. Jika terdapat perbedaan sifat pada basis dan zat aktif akan terjadi proses penggumpalan sehingga mengakibatkan bentuk sediaan yang memiliki partikel lebih besar dari sediaan Uji homogenitas dilakukan dengan cara mengamati hasil pengolesan salep pada plat kaca. Salep yang homogen ditandai dengan tidak terdapatnya gumpalan pada hasil pengolesan sampai titik akhir pengolesan. Salep yang diuji diambil dari tiga tempat yaitu bagian atas, tengah dan bawah dari wadah salep.

Hasil penelitian yang dilakukan oleh Erza (2016) Sediaan salep yang homogen mengindikasikan bahwa ketercampuran dari bahan-bahan salep serta ekstrak daun ketepeng cina yang digunakan baik sehingga tidak didapati gumpalan ataupun butiran kasar pada sediaan karena sediaan salep harus homogen dan rata agar tidak menimbulkan iritasi dan terdistribusi merata ketika digunakan ${ }^{13}$. Diketahui bahwa sediaan semi solida merupakan sediaan setengah padat yang dibuat untuk tujuan pengobatan topikal melalui kulit ${ }^{14}$. Penelitian yang dilakukan oleh Andirisnanti (2012) menejaskan bahwa daya sebar diharapkan berpengaruh terhadap kecepatan difusi zat aktif dalam melewati membran. Semakin luas membran tempat sediaan salep menyebar maka koefisien difusi makin besar yang dimana mengakibatkan difusi obat pun semakin meningkat, sehingga semakin besar daya sebar suatu sediaan maka semakin baik ${ }^{15}$.

Cream lada hitam kombinasi jahe merah efektif dalam mengobati penyakit vitiligo. Hal ini sejalan dengan penelitian yang dilakukan oleh Nasihah (2019) menyatakan bahwa cream lada hitam efektif dalam mengobati penyakit vitiligo dan sesuai dengan gambar 2, menunjukan bahwa cream lada hitam kombinasi jahe merah efektif dalam mengobati penyakit vitiligo. Terdapat perubahan luas paparan vitiligo antara sebelum dan sesudah pemberian cream lada hitam kombinasi jahe merah. Beberapa factor yang mendukung keberhasilan penggunaan cream ini adalah konsistensi pemakaian, proses perubahan yang cukup lambat tapi pasti, sehingga membutuhkan waktu yang cukup lama untuk mengatasi penyakit ini, selain itu usia pasien mempengaruhi proses penyembuhan, pasien yang lebih muda usianya lebih cepat proses penyembuhanya daripada yang usianya sudah tua., hal ini disebabkan karena sel-sel dalam tubuh masih aktif membelah dan melakukan regenarasi ${ }^{11}$. 


\section{SIMPULAN DAN SARAN}

Dari penelitian pembuatan produk cream biji lada hitam kombinasi jahe merah sebagai obat vitiligo dapat ditarik kesimpulan bawah cream biji lada hitam kombinasi jahe merah efektif dalam mengobati penyakit vitiligo dengan nilai $T$ hitung sebesar $4.583>T$ tabel 2.131. Kesimpulannya adalah terdapat perbedaan yang signifikan luas paparan vitiligo pada kulit sebelum dan sesudah diberi cream lada hitam kombinasi jahe merah. Diharapkan ada penelitian lanjutan untuk mengetahui kandungan lada hitam dan jahe yang berperan dalam mengobati penyakit vitiligo dan diharapkan hasil penelitian ini dijadikan sebagai produk yang diproduksi massal dan bisa dirasakan manfaatnya oleh masyarakat terutama penderita vitiligo.

\section{DAFTAR PUSTAKA}

1. Susila I, Mimatun N. Jurnal Nasional IImu Kesehatan. J Nas IImu Kesehat. 2019;1(2):116.

2. Sadikim RY, Sandhika W, Saputro ID. Pengaruh Pemberian Ekstrak Jahe Merah (Zingiber officinale var . rubrum ) terhadap Jumlah Sel Makrofag dan Pembuluh Darah pada Luka Bersih Mencit ( Mus musculus) Jantan ( Penelitian Eksperimental pada Hewan Coba ) ( Effect of Red Ginger [ Zingiber offic. Period Dermatology Venereol. 2018;30(2):121-127.

3. Septia U. Ramuan Alami Atasi Pudarnya Warna Kulit Akibat Vitiligo. Liputan 6.com. https://www.liputan6.com/health/read/3137276/4-ramuan-alami-atasi pudarnya-warnakulit-akibat-vitiligo. Published 2017. Accessed July 21, 2019.

4. Rahmayanti ND, Rahmadewi. Studi Retrospektif : Profil Pasien Baru Vitiligo. J Berk IImu Kesehat Kulit dan Kelamin. 2016;28(2):52-58.

5. Pratimasari D, Sugihartini N, Yuwono T. Evaluasi Sifat Fisik Dan Uji Iritasi Sediaan Salep Minyak Atsiri Bunga Cengkeh Dalam Basis Larut Air. J IIm Farm. 2015;11(1):915. doi:10.20885/jif.vol11.iss1.art2

6. Sari A, Maulidya A. FORMULASI SEDIAAN SALEP EKSTRAK ETANOL RIMPANG KUNYIT (Curcuma longa Linn). Sel J Penelit Kesehat. 2017;3(1):16-23.

7. Putu N, Hikmawanti E, Aulia C, Viransa VP. KANDUNGAN PIPERIN DALAM EKSTRAK BUAH LADA HITAM DAN BUAH LADA PUTIH (Piper nigrum L.) YANG DIEKSTRAKSI DENGAN VARIASI KONSENTRASI ETANOL MENGGUNAKAN METODE KLTDENSITOMETRI. 2016;13(2):173-185. doi:10.12928/mf.v13i2.7769

8. Simangunsong FMP, Mulyani S, Hartiati A. EVALUASI KARAKTERISTIK KRIM EKSTRAK KUNYIT (Curcuma domestica Val.) PADA BERBAGAI FORMULASI. J Rekayasa Dan Manaj Agroindustri. 2018;6(1):11. doi:10.24843/JRMA.2018.v06.i01.p02

9. Nasihah M, Fajrin FI. EFEKTIVITAS EKSTRAK BUAH LADA HITAM ( PIPER NIGRUM 
L ) KOMBINASI JAHE MERAH ( ZINGIBER OFFICINALE ) UNTUK MENGOBATI PENYAKIT VITILIGO. J Res Technol. 2019;5(2):154-167.

10. Nasihah $M$, Fajrin FI. UPAYA PENGOBATAN PENYAKIT VITILIGO MELALUI APLIKASI CREAM LADA HITAM ( PIPER NIGRUM L .) KOMBINASI JAHE MERAH ( ZINGIBER OFFICINALE ). In: SNasPPM. ; 2019:115-123.

11. Nasihah M, Susila I. Pengobatan Penyakit Vitiligo Melalui Penggunaan Cream Biji Lada Hitam (Piper nigrum L). 2019;4(1):2-8.

12. Mimatun N. EFEKTIVITAS CREAM BIJI LADA HITAM (Piper nigrum L.) TERHADAP PENYAKIT VITILIGO. 2018:10-11.

13. Erza Genatrika, Isna Nurkhikmah IH. FORMULASI SEDIAAN KRIM MINYAK JINTAN HITAM (Nigella sativa L.) SEBAGAI ANTIJERAWAT TERHADAP BAKTERI Propionibacterium acnes. Celal Bayar Üniversitesi Sos Bilim Derg. 2016;12(1):1-7.

14. Rukmana W. FORMULASI DAN UJI STABILITAS FISIK SEDIAAN SALEP ANTIFUNGI EKSTRAK DAUN KETEPENG CINA (Cassia Alata L.).; 2017.

15. Andirisnanti WA. Uji Manfaat Ekstrak Kolagen Kasar dari Teripang Stricopus hermanni sebagai Bahan Pelembab Kulit. Depok Fak Mat dan IImu Pengetah Alam Progr Magister Herba. 2012. 